\title{
GLL
}

Geomatics, Landmanagement and Landscape No. 4 • 2021, 7-18

\section{APPLICATION OF GEOMATICS TO THE MULTICRITERIA ZONING OF THE UPPER ALIBORI FOREST RESERVE IN NORTHERN BENIN (WEST AFRICA)}

\author{
Ousséni Arouna, Dramane Issiako, Briac Kévin Patrick Kossougbeto
}

\begin{abstract}
Summary
The Forest of Upper Alibori is subject to strong agricultural and pastoral pressures from year to year despite the implementation of a forest management plan. It is therefore appropriate to conduct an integrated and spatialized analysis of the effects of these pressures on plant biodiversity from a spatial planning perspective. The research objective is to establish a multi-criteria zoning of the Upper Alibori Forest Reserve that can reconcile biodiversity conservation and sustainable agropastoral exploitation. A methodological approach based on geomatics was adopted. Hierarchical multi-criteria analysis and cross-layer analysis are the main techniques adopted. The state of plant biodiversity, one of the important criteria for multi-criteria zoning. The intersection of the scientific zoning and the zoning proposed by the riparian population shows a similarity of $54 \%$. In the central core, the similarity between the two types of zoning is $32 \%$. Spatially, this similarity is observed along the Alibori River. At the level of the agricultural series, the two zonings show a similarity level of $23 \%$. The elaboration of an integrated zoning made it possible to distinguish several management series. The management series delimited are made up of the central core (32\%), the protection series (11\%), the production series $(17 \%)$, the scientific research series $(2 \%)$, the service series $(2 \%)$ and the agropastoral and reforestation series (36\%). The implementation of such zoning is the responsibility of the forest administration.
\end{abstract}

\section{Keywords}

pressures • biodiversity • geomatics $\bullet$ management $\bullet$ Upper Alibori forest reserve $\bullet$ Benin

\section{Introduction}

In sub-Saharan Africa, deforestation rates accounted for $13 \%$ of forest cover globally between 2001 and 2015. The main driver of deforestation in tropical regions is shifting agriculture, which accounts for up to $92 \%$ of deforestation [FAO 2016].

In the north of Benin, there are most of the protected areas designed to conserve plant biodiversity. It is still this part of Benin that constitutes the economic lung of the country with the production of cotton. In northern Benin, there is a real tension between conservation and economic development objectives. 
The forest reserve of Upper Alibori is located in this part of Benin which constitutes the cotton farming zone. This protected area is surrounded by the major cotton producing Districts of Banikoara, Kandi, Kérou, Gogounou, Ouassa-Péhunco and Sinendé. The forest reserve of Upper Alibori benefited from a Participatory Management Plan in 2010, developed for a period of 10 years with the support of the Forests and Riparian Lands Management Program (PGFTR). This forest management plan aimed to control anthropic pressures in this forest reserve, to restore degraded areas, to contribute to the maintenance of biodiversity while advocating for sustainable natural resource exploitation systems [DGFRN 2010]. Ten years after the implementation of this management plan, the forest reserve of Upper Alibori is increasingly threatened by agriculture, extensive cattle ranching, and illegal logging [Issiako 2021]. The protection of the forest reserve of Upper Alibori and the conservation of biodiversity is incompatible with the geographical location of this forest in the heart of the cotton farming zone of Benin. Agropastoral exploitation of this forest reserve observed in 2000 by Akindélé [2000], in 2002 by Arouna [2002], in 2010 by Danko [2014] has continued and increased [Assani Seidou et al. 2017, Issiako et al. 2018, Mama et al. 2020] despite a decade of implementation of the management plan. Deforestation and forest degradation continue in forest reserve of Upper Alibori despite the management plan developed with the participation of different stakeholders.

A fundamental issue is the spatial reorganization of this forest reserve management using a holistic geomatics-based approach after a decade of implementation of a forest management plan that has failed to conserve biodiversity.

The objective of this research is to develop a multi-criteria zoning of the forest reserve of Upper Alibori based on geomatics applications. The research hypothesis states that there is a difference between zoning based on scientific criteria and that emanating from the aspirations of local people.

\section{Materials and methods}

\subsection{Study site}

The forest reserve of Upper Alibori straddles the Provinces of Atacora, Borgou and Alibori. It is located $10^{\circ} 14$ and $11^{\circ} 40$ north latitude and $1^{\circ} 54^{\prime}$ and $2^{\circ} 55$ east longitude. It extends over six districts, namely: Banikoara, Gogounou, Kandi, Kèrou, OuassaPéhunco and Sinendé, with an area of 256 ha (DGFRN, 2010). Figure 1 shows the geographical location of the Upper Alibori forest reserve.

\subsection{GIS integration and hierarchical multi-criteria analysis process}

Mapping combined with the Hierarchical Multi-criteria Analysis (HMA) approach is the methodological approach adopted to conduct this research (Fig. 2). 


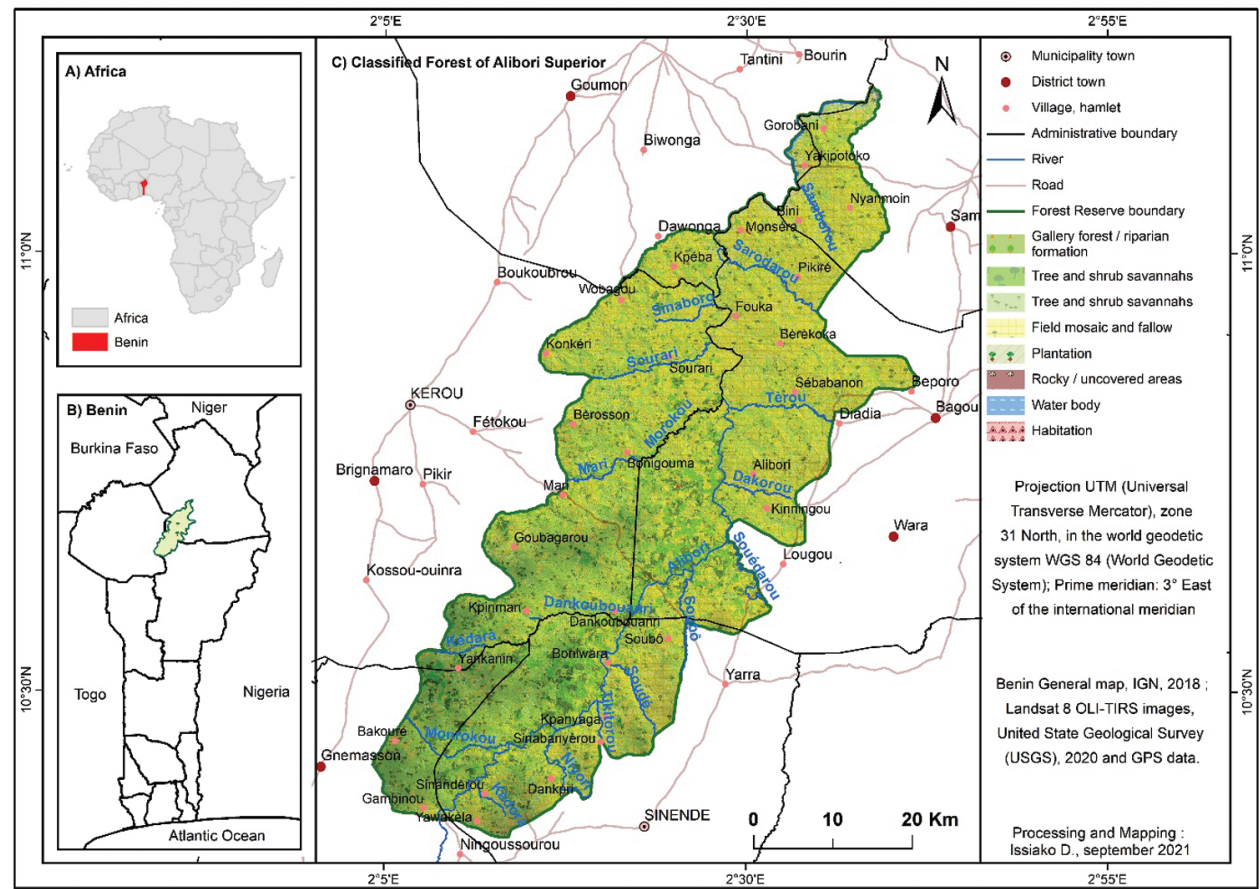

Source: Authors' own study

Fig. 1. Geographic location of the Upper Alibori forest reserve

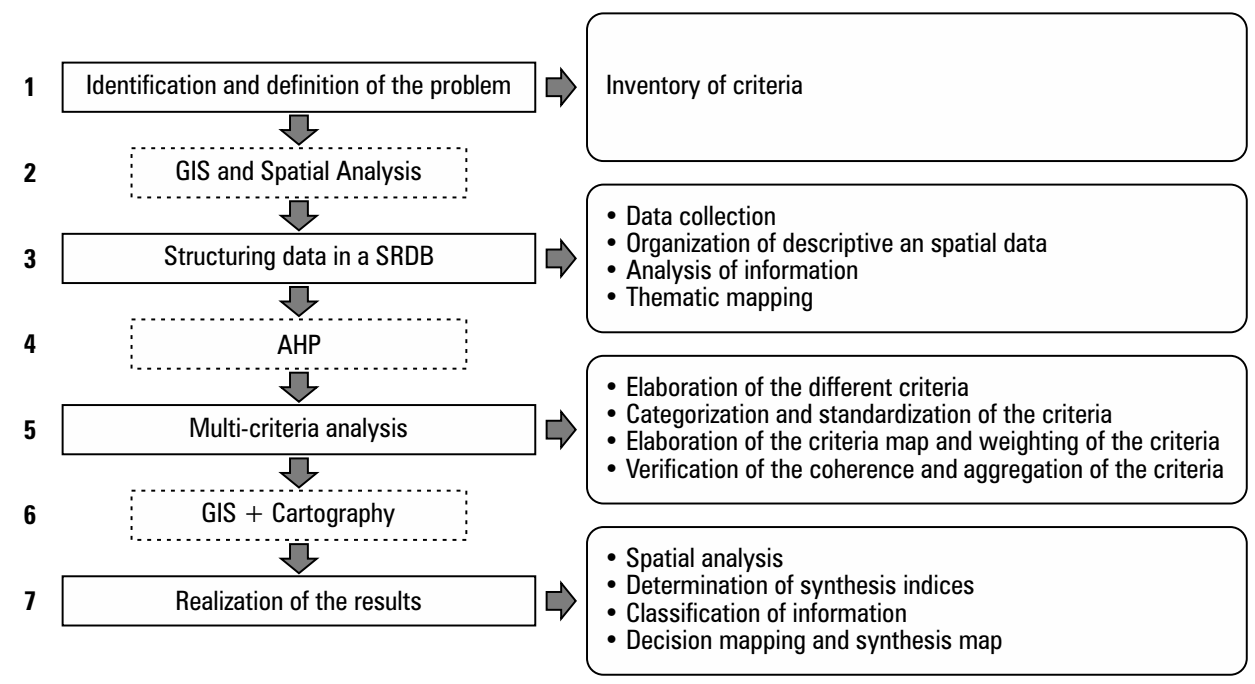

Source: Own elaboration following the decision-making process with the analytical hierarchical process of Saaty [1984]

Fig. 2. GIS and HMA integration process for spatial decision support 


\subsection{Criteria weighting}

Table I below presents the summary of the weightings and their meaning. Note that the criterion stream distribution was not weighted because the water resource is distributed almost uniformly throughout the Forest Reserve of Upper Alibori.

Table 1. Weighting of selected criteria

\begin{tabular}{|c|c|c|c|}
\hline Criterion & $\begin{array}{c}\text { Level } \\
\text { of importance }\end{array}$ & Definition & Explanation \\
\hline \multirow{3}{*}{$\begin{array}{l}\text { Specific } \\
\text { diversity }\end{array}$} & 1 & $\begin{array}{l}\text { Not very } \\
\text { diversified }\end{array}$ & $\begin{array}{l}\text { Vegetation formations with little diversity. These are } \\
\text { fields, fallows, and plantations. }\end{array}$ \\
\hline & 2 & $\begin{array}{l}\text { Moderately } \\
\text { diversified }\end{array}$ & Abundant formations. These are gallery forests. \\
\hline & 3 & Diversified & $\begin{array}{l}\text { Diversified vegetation formations. These are open forests } \\
\text { and wooded savannahs and tree and shrub savannahs. }\end{array}$ \\
\hline \multirow{3}{*}{$\begin{array}{l}\text { Density } \\
\text { of woody } \\
\text { plants }\end{array}$} & 1 & $\begin{array}{l}\text { Low } \\
\text { density }\end{array}$ & $\begin{array}{l}\text { Low densities ( } 1 \text { to } 55 \text { trees/ha) are obtained in tree } \\
\text { and shrub savannahs, plantations, fields, and fallows, } \\
\text { settlements, and rocky surfaces. }\end{array}$ \\
\hline & 2 & $\begin{array}{l}\text { Medium } \\
\text { density }\end{array}$ & $\begin{array}{l}\text { The values from } 55 \text { to } 126 \text { trees/ha are characterized as } \\
\text { medium and obtained in the class of dense dry forests, } \\
\text { open forests, and wooded savannahs. }\end{array}$ \\
\hline & 3 & $\begin{array}{l}\text { High } \\
\text { density }\end{array}$ & $\begin{array}{l}\text { The high densities are obtained in the class of gallery } \\
\text { forests with values from } 126 \text { to } 153 \text { trees/ha. }\end{array}$ \\
\hline
\end{tabular}

\subsection{Color theory and criteria weighting}

The color theory was used in the framework of the card crossing. The colors located halfway between the primary colors and obtained by mixing the adjacent colors correspond to the secondary colors by additive synthesis (Fig. 3).

The additive synthesis by superposition of the red, the green and the blue to obtain the white color. Their addition two by two makes it possible to obtain the secondary colors, namely: blue, green, cyan, magenta, yellow and red. Table 2 shows the combination of colors and the different weighted values.

The weighting scale of the criteria was made the extension spatial analyst tool $>$ Map algebra > raster Calculator. The matrix of combination of colors and scale of raster Calculator (Spatial Analyst) is presented by Figure 4.

Figure 3 shows the crossing of the primitive colors (blue (1), green (2) and red (3) to obtain the secondary colors. These colors are blue (1), cyan (2), magenta (3), green (4), yellow (6) and red (9). The explanation of the scales proposed by the raster Calculator (Spatial Analyst) according to Thomas SAATY (1984) is in Table 2. 


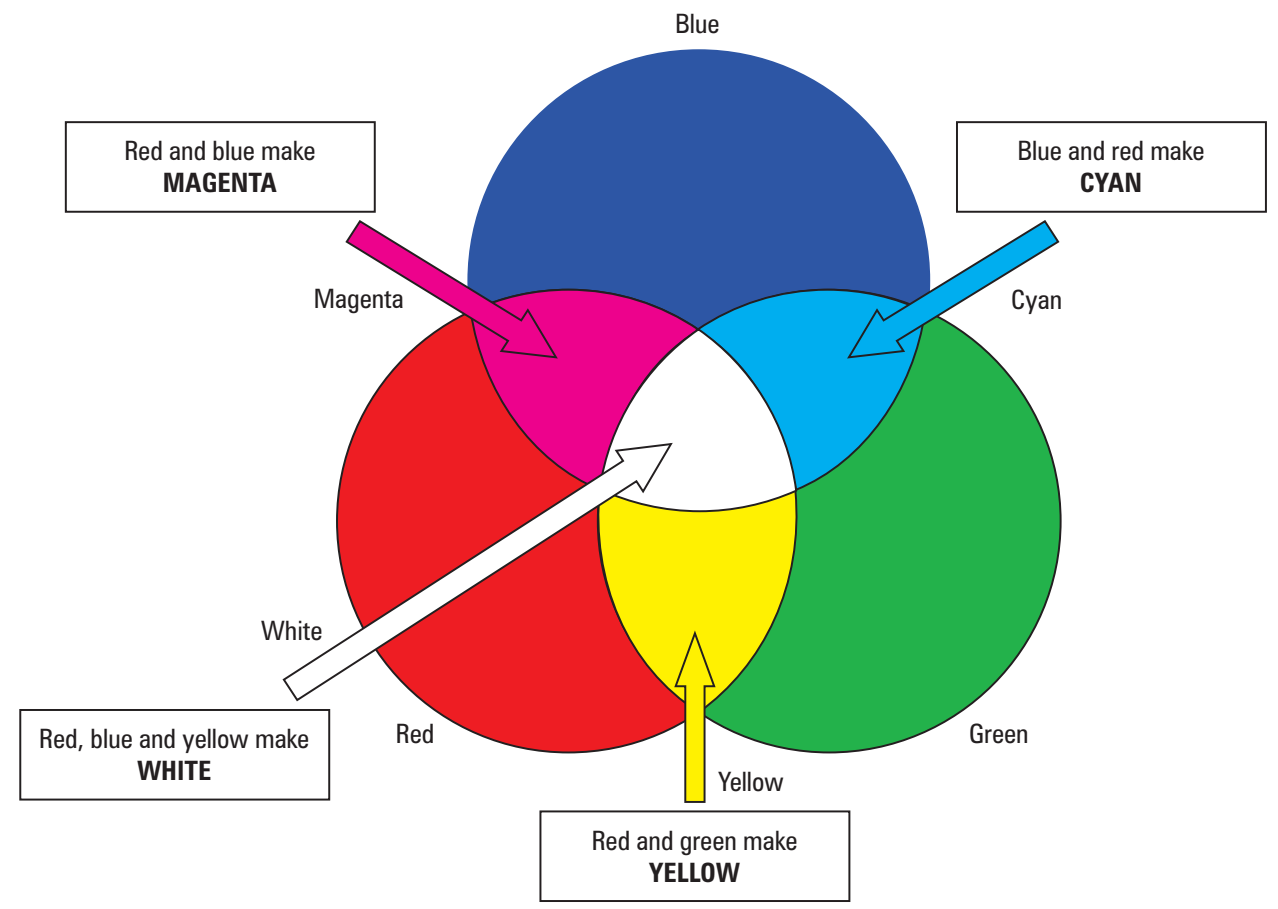

Source: Authors' own study

Fig. 3. Combination of the colors

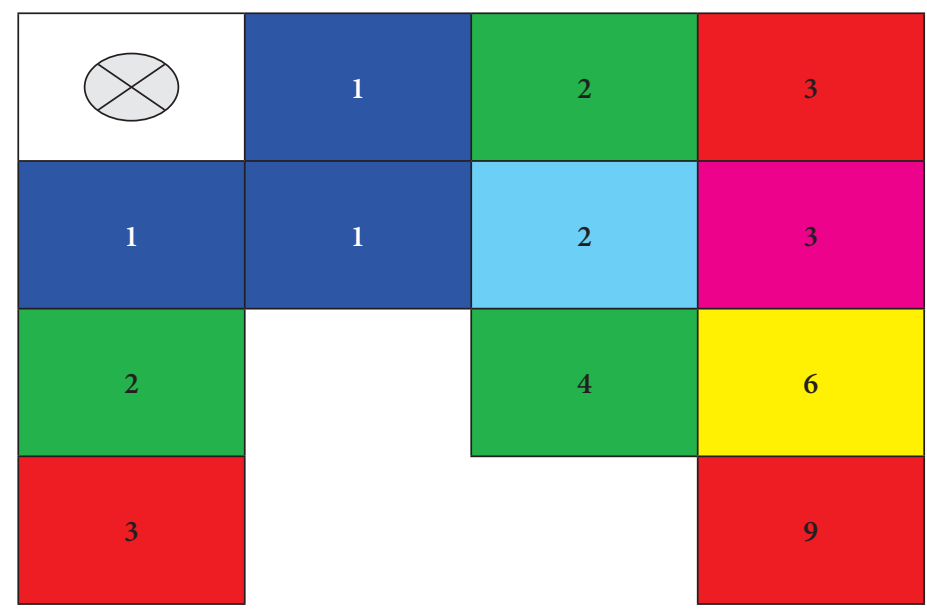

Source: Authors' own study

Fig. 4. Color combination matrix and raster calculator scale 
Table 2. Scale proposed by raster Calculator (Spatial Analyst)

\begin{tabular}{|c|l|}
\hline $\begin{array}{c}\text { Levels of } \\
\text { importance }\end{array}$ & \multicolumn{1}{c|}{ Explanation } \\
\hline 1 & Low importance: two characteristics contribute equally \\
\hline 2 & $\begin{array}{l}\text { Low importance: personal experience and appreciation slightly favor one } \\
\text { characteristic over another. }\end{array}$ \\
\hline 3 & $\begin{array}{l}\text { Strong or decisive importance: experience and appreciation strongly favor one } \\
\text { characteristic over another. }\end{array}$ \\
\hline 4 & Moderate importance: two characteristics contribute equally. \\
\hline 6 & $\begin{array}{l}\text { Strong or proven importance: one characteristic is strongly favoured, and its } \\
\text { dominance is proven in practice. }\end{array}$ \\
\hline 9 & $\begin{array}{l}\text { Absolute importance: the evidence favouring one characteristic over another is } \\
\text { as convincing as possible. }\end{array}$ \\
\hline
\end{tabular}

Source: inspired by Thomas Saaty (1984) scale table

\subsection{Reclassification and crossing of the various maps}

The identification of the most suitable areas for the conservation of the plant biodiversity was done by successively crossing the synthesis maps. Cross-referencing the maps also means cross-referencing the scores previously defined in Table 1 in order to give the appropriate characteristics to each area.

\section{Results}

\subsection{Map of plant communities}

After the reclassification, the map crossings were performed. The crossing of the specific diversity map and the gross density map resulted in the stand map (Fig. 5).

This map shows the state of plant biodiversity, one of the important criteria for multi-criteria zoning.

\subsection{Delineation of management zones based on the criteria}

Figure 6 shows the minute zoning map obtained from the intersection the plant communities map and the management zone delineation map.

The observation of Figure 6 shows that the delimitation of the management series is based on the summary map. The management series delineated are the central core $(32 \%)$, the production series $(16 \%)$, the pastoral series $(12 \%)$, the protection series $(10 \%)$, the reforestation series (3\%), the scientific research series $(2 \%)$, and the service series $(2 \%)$. 


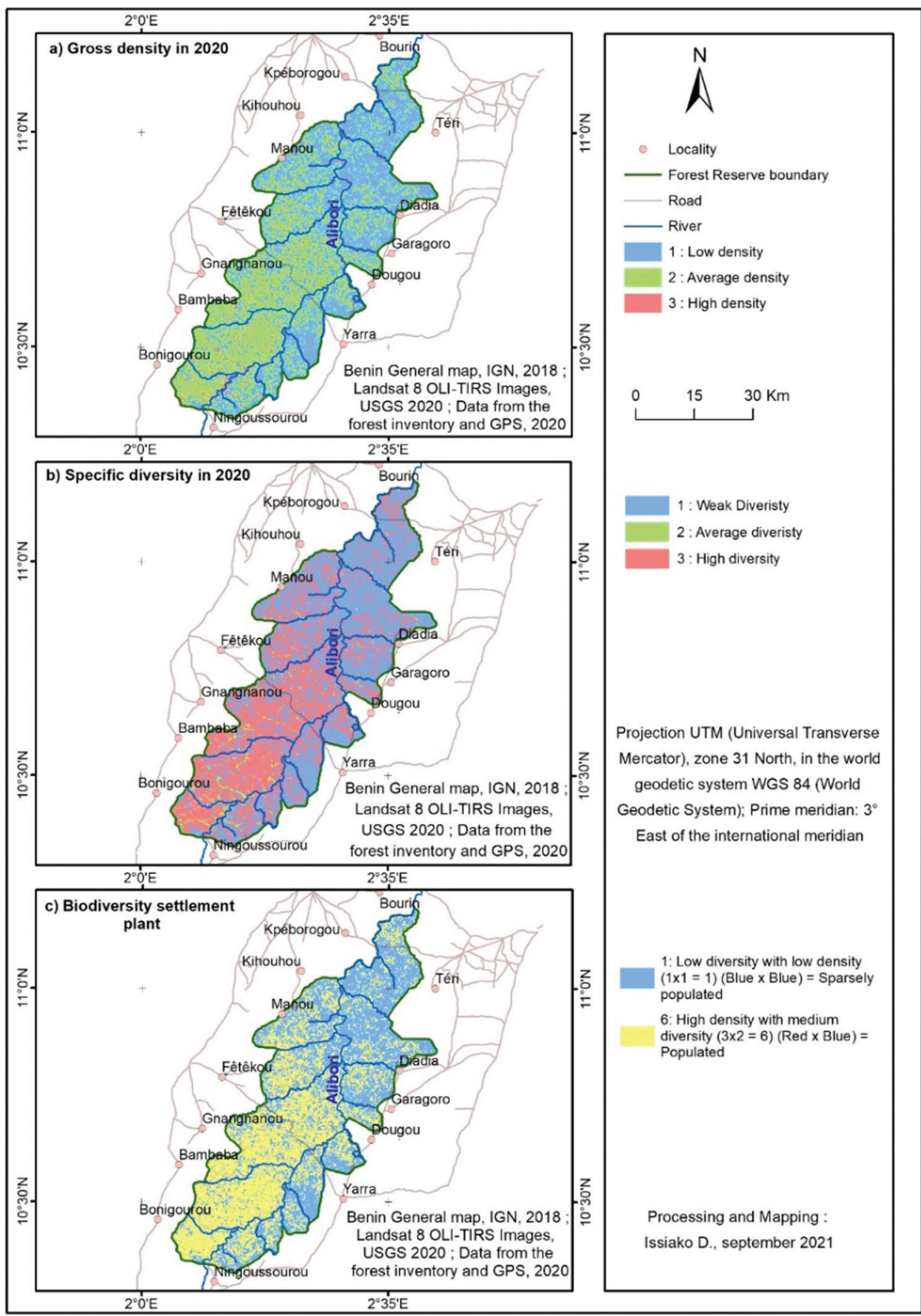

Source: Authors' own study

Fig. 5. Cross-referencing of species diversity and gross density maps: stand map 


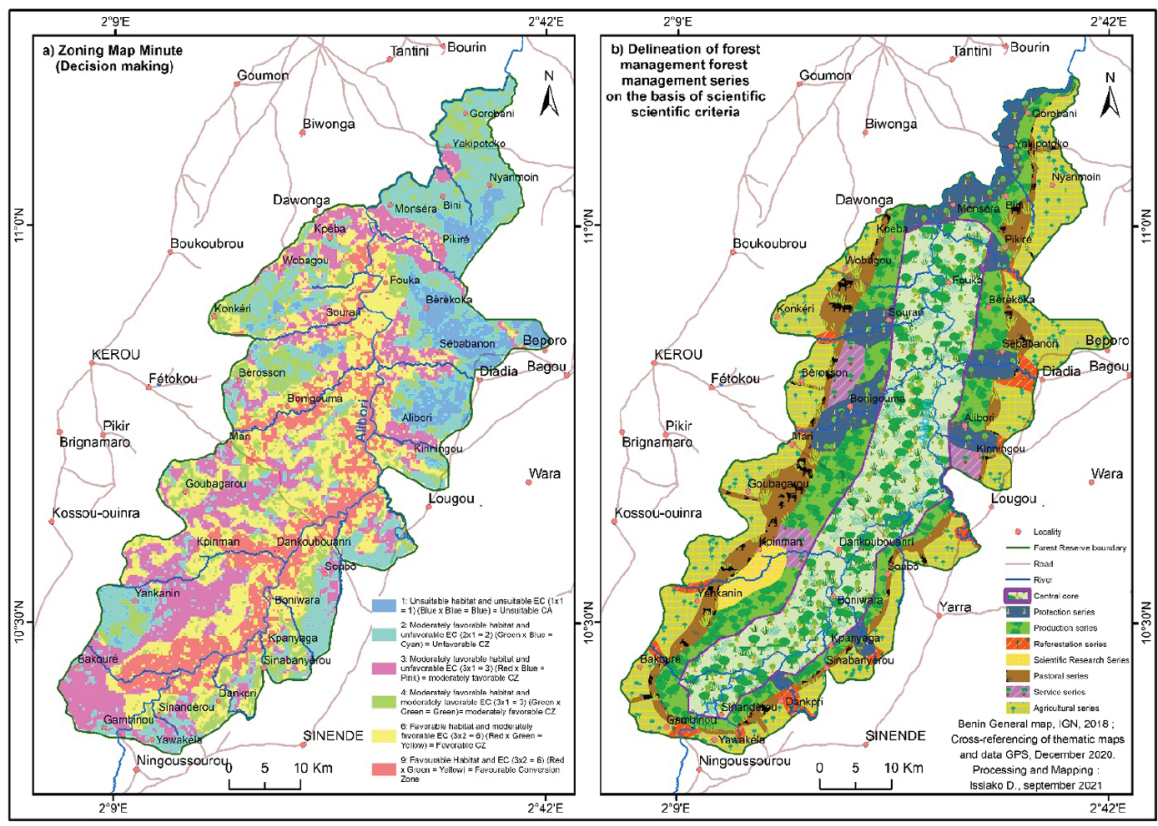

Source: Authors' own study

Fig. 6. Minute of zoning map and the delimitation map of the management zones

\subsection{Scientific and local population zoning}

Figure 7 shows the zoning based on scientific criteria and the zoning proposed by the local populations of the FCAS.

Figure 7 shows a zoning plan with eight management series (Fig. 7a) and that proposed by the riparian populations with three (3) series (Fig. 7b). The scientific method based on the cross-referencing of maps of indicative forest management criteria made it possible to delineate the central core $(10 \mathrm{~km})$ along the Alibori River, the protection series along the tributaries of the Alibori River. The production series encircled the central core with the aim of protecting it from anthropic pressures. In addition, the riparian's preferred that the central core be delineated along the drainage axes of the Alibori River and the protection series along the streams. They suggest that the central core be surrounded by the production series and the agropastoral series. Figure 8 presents the result of the cross-referencing of the zoning map established on the basis of scientific criteria and that proposed by the riparian populations.

Figure 8 shows that the intersection of the scientific zoning and the zoning proposed by the riparian population shows a similarity of $54 \%$. In the central core, the similarity between the two types of zoning is $32 \%$. Spatially, this similarity is observed along the Alibori River. At the level of the agricultural series, the two zonings show a similarity level of $23 \%$. 


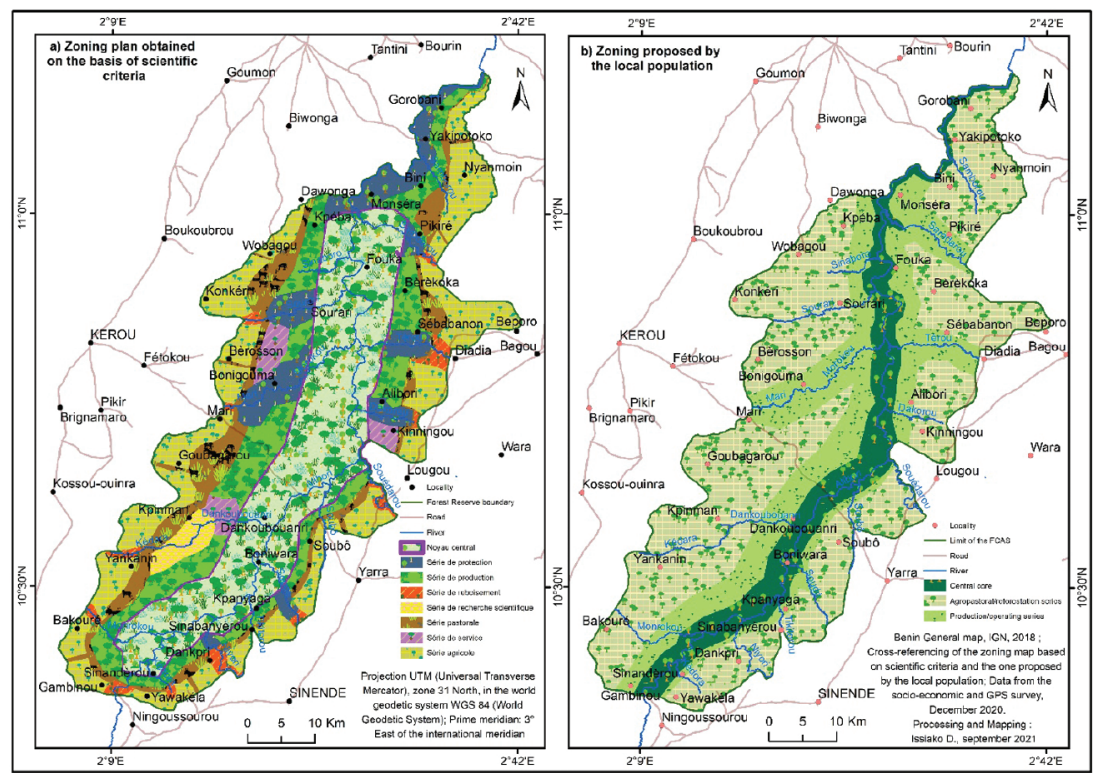

Source: Authors' own study

Fig. 7. Zoning based on scientific criteria and zoning proposed by the local population of the Upper Alibori Forest Reserve

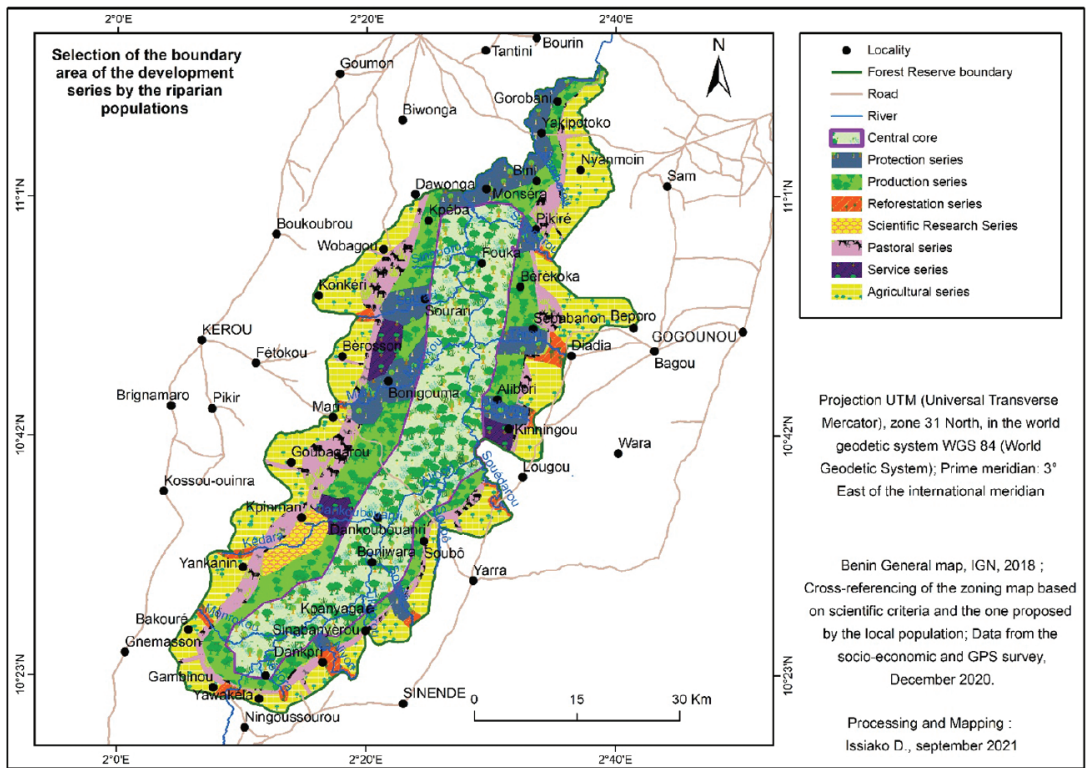

Source: Authors' own study

Fig. 8. Integrated zoning of the Upper Alibori forest reserve 


\section{Discussion}

The spatial analysis of the Upper Alibori Forest Reserve has highlighted potential areas for biodiversity conservation. The analysis of the Shannon diversity index shows that woodlands and tree and shrub savannahs are the most diverse [1.73 - 2 bits] with a score equal to 3. Gallery forests are moderately diverse with a Shannon index that varies between [1.66 - 1.73 bits] and the score is equal to 2. Finally, field, and fallow mosaics, plantations are weakly diverse ( $\leq 1.60 \mathrm{bit}$ ) with a score equal to 1 . These values of Shannon index observed in forests and savannahs testify to the degree of specific diversity of the occupied areas. This high diversity index also confirms the importance of the ecological potentialities of the study area [Gning 2008].

The plant community map resulting from the cross-referencing of the density map with the diversity map reveals that the southwest and central areas are populated and diverse. This observation is also made by Ngom et al. [2012], the less anthropized the area the more populated it is. The peripheries of the forest are the low diversity areas. These low values in the peripheries confirm that plant species are highly threatened by the anarchic installation of fields. In other words, there is a huge conflict between the objective of conservation and local economic development, especially agriculture and extensive livestock. This conflict of objectives is materialized by the zoning maps resulting from the crossing of the thematic maps and the zoning map proposed by the riparian populations. The differences can be seen especially in the central core intended for biodiversity conservation and the agricultural and pastoral zones. This difference in terms of area is $46 \%$. The research hypothesis that there is a difference between zoning based on scientific criteria and that emanating from the aspirations of local populations is thus verified.

A new alliance between the flora, vegetation, waterways, soil, and landforms that make up the natural environment allowed the delineation of potential conservation zones in the Upper Alibori forest reserve. This seems to be one of the preferred ways to manage biodiversity for sustainable development and to prevent the explosion of multiple conflicts [Ngom et al. 2012].

\section{Conclusion}

The combination of spatial information analysis and hierarchical multi-criteria analysis (HMA) has allowed us to evaluate potential areas for forest resource conservation for decision support. This is a more thorough and objective scientific approach. It is based on raw data on flora, vegetation, soil, waterways, and terrain. This raw data was spatialized, reclassified and cross-referenced in an objective manner. Six development series were delineated and validated.

The zoning proposed by the riparian populations includes three series. There is an opposition between the zoning based on scientific criteria and that of the local populations, attesting the tension between the objectives of conservation and those of local economic development. 
The emergence of rational management of forest resources, in order to respond to environmental challenges and socio-economic issues, must reconcile scientific zoning with the zoning desired by local populations. This consideration is the main contribution of this article.

\section{References}

Arouna O. 2002. L’exploitation des ressources biologiques et la dynamique de la forêt classée de l'Alibori supérieur au Bénin (secteur de l’arrondissement de Bagou). Mémoire de maîtrise. DGAT, FLASH/UAC. Bénin.

Assani Seidou A., Agbayigbo A-A., Alkoiret Traore I., Houinato M. 2017. Spatial-temporal Dynamics of Natural Rangelands Exploited by Transhumance Cattle Herds in the Classified Forest of Upper Alibori, Northern Benin. American Scientific Research Journal for Engineering, Technology, and Sciences (ASRJETS), 33, N01, 111-123.

Berger F., Rey F., Liévois J. 2003. Le zonage: un outil pour la gestion des forêts de montagne à fonction de protection contre les risques naturels. Ingénieries - E A T, IRSTEA, 53-63.

Bland L.M., Regan T.J., Minh Ngoc Dinh, Ferrari R., Keith D.A., Lester R., Mouillot D., Murray N.J., Hoang Anh Nguyen, Nicholson E. 2017. Using multiple lines of evidence to assess the risk of ecosystem collapse. Proc. R. Soc. B 284: 20170660. http://dx.doi.org/10.1098/ rspb.2017.0660.

Chevallier M. 2015. Mise en œuvre d'un outil SIG et d'un processus d'analyse multicritère semiautomatisé pour l’aménagement du territoire: application dans le cadre de la révision du SCoT des Vosges Centrales. Sciences de l'ingénieur [physics].

DGFRN. Direction Générale des Forêts et Ressources Naturelles. 2010. Plan d'Aménagement Participatif de la Forêt Classée de l'Alibori Supérieur (PAP-FCAS) 2010-2019. Bénin.

Djogbénou C.P. 2010. Analyse multicritère des Plans d’Aménagement et de Gestion participatifs des forêts classées au Bénin: développement d’un modèle durable. Thèse de Doctorat. Université d'Abomey-Calavi.

Djuidje D. 2020. Compétition entre utilisations des terres et plan de zonage forestier au Cameroun. Faculté des sciences. Université catholique de Louvain. http://hdl.handle.net/2078.1/ thesis: 24276

FAO. 2015. Évaluation des ressources forestières mondiales. http://www.fao.org/publications

FAO. 2016. Forêts et agriculture: défis et possibilités concernant l'utilisation des terres. Rome, Italie. FAO.

FAO. 2018. La situation des forêts du monde. Les forêts au service du développement durable. Rome, Italie. FAO.

Gning O.N. 2008. Caractéristiques des ligneux fourragers dans les parcours communautaires de Khossanto (Kédougou, Sénégal Oriental). Mémoire de DEA en Biologie végétale. UCAD.

Gouwakinnou G.N., Biaou S.S.H., Biaou S., Houeto O.F. 2018. Effet des changements d'occupation des terres sur le flux du carbone: un exemple des forêts classées de l'Alibori supérieur et de Ouénou-Bénou au Bénin. In: Actes de la conférence scientifique internationale OSFACO: Images satellitaires pour un meilleur aménagement des territoires et une gestion durable de la biodiversité, 193-2010.

Issiako D., Arouna O. 2018. Dynamique de l'occupation des terres avant et après l'élaboration du plan d'aménagement participatif de la forêt classée de l'Alibori Supérieur au Nord-Benin. In: Actes de la conférence scientifique internationale OSFACO: Images satellitaires pour un meilleur aménagement des territoires et une gestion durable de la biodiversité, 193-2010. 
Lamb D., Erskine P.D., Parrotta J.A. 2005. Restoration of Degraded Tropical Forest Landscapes. Science, 310, 1628. DOI: 10.1126/science.1111773.

Mama A., Oumorou M., Sinsin B., de Canniere C., Bogaert J. 2020. Anthropisation des paysages naturels des aires protégées au Bénin: cas de la Forêt Classée de l’Alibori Supérieur (FC-AS). American Journal of Innovative Research and Applied Sciences, 11(2), 117-125.

Mantran M., Lucien-Brun M., Angeon V. 2017. Le zonage agroécologique aux Antilles françaises: un outil de définition du potentiel agricole et d'aide à la décision en matière d'amélioration des choix de production.

Munoz A., Bock J., Monnet J.M., Renaud J.P., Jolly A. 2016. Évaluation par validation indépendante des prédictions des paramètres forestiers réalisées à partir de données Lidar aéroporté. Revue Française de Photogrammétrie et de Télédétection, Société Française de Photogrammétrie et de Télédétection, 211-212, 81-92.

Sidle J.G., Dupain J., Beck J., Nackoney J., de Wasseige C., Mendomo J.D., Leprohon R., Malele S. 2011. Expérience du zonage forestier en Afrique centrale. In: de Wasseige C., de Marcken P., Bayol N., Hiol Hiol F., Mayaux Ph., Desclée B., Nasi R., Billand A., Defourny P. et Eba'a Atyi R. (eds.). The Forests of the Congo Basin - State of the Forest 2010, Luxembourg. Publications Office of the European Union, 207-231.

Zakari S., Toko Imorou I., Arouna O., Mama D., Thomas O. 2019. Évaluation de la déforestation et de la dégradation des forêts dans les aires protégées et terroirs villageois du bassin cotonnier du Bénin. Conférence OSFACO: Des images satellites pour la gestion durable des territoires en Afrique, Mars 2019. Cotonou, Bénin. https://hal.archives-ouvertes.fr/hal02189556 .

PhD Ousséni Arouna

Zou, Laboratory of Geosciences, Environment and Applications

National University of Sciences, Technologies,

Engineering and Mathematics (UNSTIM), Benin

e-mail: arounaousseni@gmail.com

ORCID: 0000-0002-4376-3281

PhD Dramane Issiako

Atlantique, Cartography Laboratory (LaCarto)

University of Abomey-Calavi (UAC), Benin

e-mail: dramaneissiako@gmail.com

ORCID: 0000-0002-2237-9475

PhD Briac Kévin Patrick Kossougbeto

Zou, Laboratory of Geosciences, Environment and Applications

National University of Sciences, Technologies,

Engineering and Mathematics (UNSTIM), Benin

e-mail: bkossougbeto@yahoo.fr

ORCID: 0000-0001-8332-6134 